\title{
Strategic Macro-Environmental Factor Analysis for Entry into the Fish Vaccines Market in India
}

\author{
Mahendra Kumar Pallapothu ${ }^{1}$ \& Juergen Krause ${ }^{1}$ \\ ${ }^{1}$ School of Business, University of Prince Edward Island, Charlottetown, PE, Canada \\ Correspondence: Mahendra Kumar Pallapothu, 29 Commonwealth Ave, Charlottetown, PE, C1E 2E7, Canada. \\ Tel: 1-902-367-9890. E-mail: pallapothu@yahoo.com
}

Received: December 25, 2012

Accepted: January 6, 2013 Online Published: January 15, 2013

doi:10.5539/ijbm.v8n3p27

URL: http://dx.doi.org/10.5539/ijbm.v8n3p27

\begin{abstract}
Globally, the aquaculture segment continues to be the fastest growing food-fish producing segment and for India, the second largest food-fish producing country, it was forecasted that the segment would grow at an average annual growth rate of approximately $7.0 \%$ to reach a total production target of 8-10 million tons by 2020 . Currently no commercial fish vaccines are available in India; therefore, the macro-environmental factors with respect to the competitive, political, economic, socio-cultural, technological, and legal landscapes, which influence a potential entrant's strategic business decisions to set up a fish vaccines company, are evaluated. The results indicate that although the macro-environmental factors in India are improving there are still some bureaucratic hurdles to be overcome by an entrant to assure success.
\end{abstract}

Keywords: macro-environmental factors, aquaculture, fish vaccines, carp vaccines, cpestl analysis

\section{Introduction}

Aquaculture is defined as the farming of aquatic organisms with some form of intervention in the rearing process to enhance production (FAO). Globally, aquaculture continues to be the fastest-growing food producing segment with an average annual growth rate (AAGR) of 8.2\% between 2004 and 2009. The segment is comprised of 336 species with the Carp species dominating the Asia/Pacific region while the Salmonid species dominate Europe, North and South America. China is the world leader in fish production and the total share of developing countries is greater than 90\% of the world's production (FAO, 2012). From 2004 to 2009 , an increase of 38\% and 53\% was reported for the freshwater and marine fish production, respectively (Ayyappan \& Gopalakirshnan, 2008). One of the impediments described to negatively impact the growth of global aquaculture production are the losses due to bacterial and viral diseases (Abraham, Sil, \& Vineetha, 2010). Therapeutic agents such as antibiotics and other drugs (Bharathkumar \& Abraham, 2011) are being employed in disease management of farmed fish, and vaccines have gained prominence as an eco-friendly alternative (Subasinghe, 2009).

The target country of this research is India, which is the world's second largest food-fish producing country (Brugère \& Ridler, 2004). In India the inland aquaculture production has increased substantially from 1.55 million tons in 2000 to 3.72 million tons in 2010 (FAO-Statistics, 2010) and is forecasted to reach between 8-10 million tons by 2020 (Paroda \& Praduman, 2000). The Carp species, namely, Catla, Rohu and Mrigal, dominated the aquaculture segment amounting to $87 \%$ of the overall production (Abraham et al., 2010). Exotic species like Silver carp, Grass carp, 10 other minor carp species and catfish (Magur and Singhi) are gaining importance (Ayyappan \& Gopalakirshnan, 2008). Katiha et al (2005) estimated that 45\% and 50\% increases in horizontal (land area for aquaculture) and vertical (productivity per farm site) expansion are possible allowing meeting the demand of 8-10 million tons by 2020. Some of the reasons for the lack of success in vertical expansion of the Indian aquaculture industry were attributed to bacterial or viral disease outbreaks and poor disease resistance in the cultivated species (Das \& Gupta, 2007). Therefore, aquaculturists are relying on chemotherapeutic agents; however, the overuse and abuse of these compounds have raised concerns such as multidrug resistance development in fish pathogens, and environmental (Parthasarathy \& Ravi, 2011) and human health hazards. Alternatives such as vaccines were suggested to increase profits, productivity and sustainability of the Indian aquaculture segment by Behera and Swain (2012), Subasinghe (2009) and Swain et al. (2010). Since the Indian aquaculture segment is an untapped market for fish vaccines, and the market is 
expected to grow at an AAGR of approximately $7.0 \%$ to reach 2020 target, a significant potential for the establishment of a new fish vaccines business exists.

For any entrepreneur or investor the decision to set up a business in a given country is determined by influences in the external company environment such as competition, political, economic, socio-cultural, technological, and legal factors. Therefore, the authors chose to evaluate the Indian aquaculture market to enable a new entrant to develop a strategy for entry into the fish vaccines business sector. Furthermore, since fish vaccines fall under the biopharmaceutical segment of the biotechnology industry and are highly regulated, an understanding of the macro-environmental factors that affect this specific industry is also important for the new entrant in strategic decision making. To the authors' knowledge, this is the first approach describing the macro-environmental factors that may help an entrant to introduce commercial fish vaccines in India, although experimental vaccines are reportedly being tested by research institutions (Behera \& Swain, 2012; Maiti, Shetty, Shekar, Karunasagar, \& Karunasagar, 2011; Maiti, Shetty, Shekar, Karunasagar, \& Karunasagar, 2012).

\section{Literature Review}

\subsection{Macro-Environment Factors}

Strategic management scholars theorized that the environment exogenous to a company has a strong influence on its strategic decision making and has to be constantly dealt with by the managers to maintain their firm's strategic position and retain profits (Aapo Länsiluoto \& Tomas Eklund, 2008; Chung-An, 2008; Hamel \& Prahalad, 1994). These dynamic changes in the surrounding environment may lead to uncertainties, impose constraints or may create opportunities and help the management to avoid potential threats (Babatunde \& Adebisi, 2012). Only those firms that are vigilant about the changing environment will succeed in taking corrective measures to remain competitive (Bourgeois III, 1985; Lumpkin \& Dess, 1995; Porter, 1986) and become more efficient than their rivals (Fombrun \& Shanley, 1990; Gimeno \& Woo, 1996). Additionally, a company must design its strategy to either confirm to the norms of its industry environment or to reshape its industry structure by introducing a radically new strategy (Hill \& Jones, 2006). The macro-environmental factors such as competitive, political, economic, socio-cultural, technological, environmental and legal factors (Armstrong \& Kotler, 2011; Fifield \& Gilligan, 1997) not only influence a firm's activities in the short-term but also impact its long-term sustainability (Wheelen \& Hunger, 2002). Goodnow and Hansz (1972) defined environmental determinants for successfully choosing an entry country. They defined the success factors as political stability, high market opportunity, economic development and performance, cultural unity, low legal barriers, physiographic barriers (infrastructure, climate, population density and land area) and geocultural distance. An understanding of these macro-environmental factors is therefore essential for an entrant before establishing a new company in the entry country of choice.

\section{Research Methodology}

As a first step to assess the business environment of a planned country for entry, a strategic macro-environmental factor scanning was conducted using the framework of competition, political, economic, socio-cultural, technological, and legal factors (CPESTL) that are external to the firm's environment but have a direct influence on the business decisions for the potential entry into a new market. This scanning exercise can enable the firm to take advantage of opportunities and make contingency plans for any potential threats. Based on this approach, the authors determined that descriptive exploratory research is a suitable method of choice. Evidence presented in this paper was gathered from peer reviewed journals, and secondary anecdotal sources such as periodicals, expert commentaries, consultancy reports, the World Bank's Global Competitive Indices and government reports such as budget plans.

\section{Analysis}

\subsection{The Competitive Landscape in the Fish Vaccines Segment in India}

Competition in a market of choice is an important driver that determines the investment into a segment. At present there are no direct competitors for commercial fish-vaccines other than universities (Dipangka \& Dibyendu, 2012; Harikrishnan, Balasundaram, \& Heo, 2012; Maiti et al., 2012; Rajesh Kumar et al., 2008) and research institutes (Behera \& Swain, 2012; Swain et al., 2010) which provide experimental vaccines. The most likely competitors in India are substitute manufacturers such as Hindustan Ciba-Geigy Ltd, Glaxo Laboratories, etc., who are supplying chemotherapeutic agents for aquaculture enterprises (Pathak, Ghosh, \& Palanisamy, 2000). Aggressive competition based on price from these substitute providers may be an issue for a new entrant who is aiming to keep the vaccine products attractive to the aquaculturists from a financial perspective. International fish vaccine enterprises such as Novartis, Centrovet, or Pfizer and local veterinary vaccine firms 
such as Ventri Biologicals etc., also constitute potential future competitors. Constraints such as the diversity of fish species, the size discrepancies of fish farms, lack of biological knowledge of Asian fish species (Walker, Lester, \& Bondad-Reantaso, 2005), diverse pathogenic strains (Swain et al., 2010) and the price sensitivity of the aquaculturists were described as limiting factors for the existing international firms to invest in Asia. However, Intervet Norbio, an aqua health division of multinational company, Merck, has already initiated its $\mathrm{R} \& \mathrm{D}$ efforts in Singapore to develop vaccines for warm water fish species.

\subsection{Political Landscape}

The political structure and systems are key factors that drive the policy and shape the incentives for entrepreneurs to select an entry country (Keren, 2009). India is the world's largest democratic country and a federal republic with three branches of governance: the legislature, the executive and the judiciary. The federal legislature is a bicameral parliament with the President as the constitutional head of the country but the executive power is conferred to the Prime Minister and the state legislations may be unicameral or bicameral, with a Chief Minister as head of the state (Datamonitor, 2011).

In India, the leftist political ideology calling for 'India to be built by Indians,' ideological divisions among pluralistic political parties, and the political weakness of the current United Progressive Alliance government due to unstable coalitions are impeding the creation of a 'business-friendly' national policy (Keren, 2009). Despite these weaknesses, India's political system was described as more stable and institutionalized than other developing countries (French, 2011), as the Indian politicians strive for policies that address the nation's needs (ICON Group, 2007) and ensure policy continuity even as governments change (Narasimhan, 2012). In such an unstable political environment, Indian entrepreneurs are reported to be more innovative than their Chinese counterparts in conceptualizing and implementing novel strategies to develop new products (Keren, 2009). In general, politicians at all levels of government support foreign investment and trade, evidenced by the presence of international enterprises such as Pfizer Inc., Novartis, etc. in India (ICON Group, 2007). The policy change started in the year 1991 and successive governments have sought to pursue a knowledge-based economy by opening the Indian market and reducing government control on foreign trade and investment. Tariffs on imports were reduced from 90\% in 1991 to 30\% in 1997 (The Economist, 2009). Accordingly, India has established a National Biotechnology Development Strategy (NBDS) in 2008 (Mroczkowski, 2011) allowing Foreign Direct Investments (FDI) into the biotechnology industry, which reached USD 10 billion by the end of the last decade. In 2006 India became the only Asian country after Singapore with significant biotechnology FDI (Pereira, 2006). Political attention was garnered by the fisheries sector with the introduction of the Model Bill in 2006 aiming to develop inland fisheries and aquaculture in a sustainable manner (Ayyappan, 2006). Property rights are bipolar depending if a state favors the entry of new firms or not. A case of property rights being too restrictive was illustrated in the state of West Bengal (WB), where local agricultural interests prohibited building a manufacturing plant for the Tata's Nano car (Keren, 2009). In the state of Andhra Pradesh (AP) on the other hand, required land was provided to Novartis for building its Bioinformatics Centre (Mathew, 2008). Therefore, the diverse political agendas of different states can threaten the economic freedom (Weede, 2010).

The 2011-2012 survey of governance indicators conducted by the World Bank Development Economics Research Group revealed a decline in five of the six governance indicators in India, namely, political stability, government effectiveness, regulatory quality (Schwab, 2011), rule of law (BMIL, 2012), and control of corruption (BMIL, 2012; Schwab, 2011), while the voice and accountability indicator improved (Schwab, 2011). However, the government has agreed to accept the Jan Lokpal Bill for approval in 2011 to control corruption. Therefore, the transaction costs for businesses are high (Keren, 2009; Prime, Subrahmanyam, \& Lin, 2012) until the Jan Lokpal Bill is passed into a law and until improvements in the above five governance indicators, which are dwindling India's competitiveness are achieved. National security and the political relationship with neighboring countries such as China and Pakistan is also a potential downside (Datamonitor, 2011).

\subsection{Indian Economy}

The economic policy of an entry country enables investors to determine the growth potential of the industry and to assess the alignment of the policy with their own business interests. The economic policy of 1991 in India is one such policy that accelerated the economic growth making India one of the fastest growing economies in the region. The GDP growth rate, although it reached $8.4 \%$ in 2011 , has declined to $6.9 \%$ in 2012 , due to the trailing effects of 2008 global economic meltdown but is forecasted to reach $7.5 \%$ in 2013 (The World Bank, 2012). The inflation rate is expected to decrease from $11.3 \%$ in 2011 to $4.0 \%$ by 2016 due to the Reserve Bank of India's revised monetary policy. The fiscal deficit in 2010 was $6.4 \%$, but India started already in 2002 to repay its liabilities to International Monetary Fund. The debt-to-GDP ratio stood at $69.2 \%$ in 2011, indicating a 
high risk for investments and high borrowing costs (Datamonitor, 2011); however, economists have shown that this ratio can be as high as $70 \%$ without compromising economic growth (Miller, Holmes, \& Feulner, 2012). India is recognized for its mature financial and capital markets with strong regulatory frameworks to control 23 stock and other capital markets under the Securities and Exchange Board of India Act of 1992. The household savings rate is fairly high, standing at $25 \%$ of its GDP. The household disposable income grew at an average rate of 13\% during 2000-2010 (USD 5386/household in 2010) and the total expenditure per household grew at a rate of $16 \%$ in 2010 . To increase the momentum for exports, the government has signed international trade agreements and created policy incentives for sectors in foreign trade. The United Nations Conference on Trade and Development ranked India as the second and Ernst \& Young as the fifth most preferred global FDI destination over the next three years. Additionally, Standard \& Poor's revised credit rating for India has improved from 'negative' to 'stable' in March 2010, while it retained its long-term sovereign rating at 'BBB minus' and short-term rating at 'A-3' due to high debt burden and the fiscal deficit. This improved credit rating is expected to lower the cost of overseas debt for Indian companies (Datamonitor, 2011). According to the Global Competitiveness Report 2011-2012 (2011-2012 GCR), India is one among 37 factor-driven economies (dependency on unskilled labor, natural resources, while selling basic commodities and competing on low prices) and is slowly catching up in innovation, infrastructure, macro-economic environment, higher education and training, health and primary education etc., to transition into an efficiency-driven economy such as China. In this endeavor, India has now established institutions that are on par with Chinese and South Korean counterparts and the next step is to leverage the institutional know-how and build Public-Private-Partnerships (PPP) to accelerate the economic growth while improving other factors stated previously (Schwab, 2011).

The biotechnology sector has a major role to play in India's economy. Overall revenues reported in 2011 exceeded USD 4.0 billion, a $21.5 \%$ increase from the previous year and are forecasted to reach USD 8.0 billion by 2015 (Datamonitor, 2011). The sector has 800 companies and exports $70 \%$ of its products contributing $60 \%$ of the global health vaccines (Myint, 2011). Government funding for the life sciences sector steadily increased 16 fold from the $8^{\text {th }}$ five year plan (1992-1997) to the $11^{\text {th }}$ five year plan (2007-2011) (Bhan, 2006). Fiscal incentives (tax breaks for R\&D spending) and policy incentives (for example, institutional infrastructure like biotech parks etc.) are in place to encourage investment in biotechnology (A. Kumar, 2007). An improved healthcare infrastructure, higher disposable incomes and improved Intellectual Property Rights (IPR) were suggested as the key growth drivers in this sector (Datamonitor, 2011).

The fisheries sector has been recognized for its increasing contributions from $0.75 \%$ to $1.04 \%$ to India's gross GDP and from $2.17 \%$ to $5.93 \%$ to the agriculture GDP between 1980 and 2005 (B. G. Kumar \& Datta, 2008). As a result, the fisheries sector has secured a government investment of $\sim$ USD 0.62 billion towards development of PPP, technology transfer, institutional restructuring, etc. in the $11^{\text {th }}$ five year plan (2007-2011) (GOI-Entrepreneurship), while the Division of Fisheries received USD 35.33 million for R\&D in fisheries and aquaculture (B. G. Kumar \& Datta, 2008). The Marine Products Export Development Authority (MPEDA) was set up to promote aquaculture, increase exports, specify standards, assist in marketing, provide training, etc. and all states now have fisheries departments focusing on the overall development of the sector (Aqua Overview). Import tariffs on fish feeds (GOI-MoF, 2011) and the $20 \%$ duty on oil-meal, a component in fish feed (Thukral $\&$ Dutta, 2012), were abolished to facilitate production and exports.

\subsection{Socio-Cultural Landscape}

Socio-cultural factors are vital for a new entrant and respective investors for the purposes of communication, employee training, design of a benefits package and choosing an appropriate leadership style to manage the business successfully.

India is a multicultural, secular nation with a caste-based societal structure. Hinduism constitutes the largest religion (80.5\%), followed by Islam (13.4\%), Christianity (2.3\%), and others (3.8\%). India has 1.2 billion people with an annual population growth rate of $1.344 \%$ and is the second most populous nation in the world after China. The median age is 25 years and $75 \%$ of the population is below 15 years of age, which gives India a competitive edge in terms of work force over other nations in coming years (Index Mundi, 2012). In terms of the Human Development Index (HDI), India ranked 134 (HDI=0.547) out of 187 countries in 2011 due to poor performance in social indicators (health, education and income), falling below the South Asian average of $\mathrm{HDI}=0.548$ (UN-HDI, 2011). A survey report from 2010 revealed that the unemployment rate in 2004-2005 in rural India had improved from $8.2 \%$ to $6.8 \%$ and in urban areas from $8.3 \%$ to $5.8 \%$ (The Economic Times, 2012). The Government of India (GOI) launched a mandatory Employees' Provident Fund and Employee Pension Scheme for government employees matching the associate's pension contribution up to $10 \%$ of their salary. Similar measures were implemented for private sector workers (Datamonitor, 2011). India's coastal 
fishing industry is categorized as an unorganized sector, in which $99 \%$ of the workforces do not receive any social security benefits, and due to declining common pool resources, many are changing their occupation to seasonal laborers in agriculture (A. Kumar, Katiha, \& Joshi, 2003). Child labor is a prevailing concern globally including India where children constitute $40 \%$ of the workforce (Halim, 2010).

The literacy rate in the country totaled $74.04 \%$ in 2011 (with the exception of the state of Kerala where literacy rate reached $100 \%$ ), an increase of 9.2 percentage points from 2001 results, while in China it is $90 \%$. The gap between male and female literacy rates shrank from 21.6 to 16.7 percentage points from 2001 to 2011. Universal elementary education is in place for children of ages 6 to 14 to improve the situation (Datamonitor, 2011). In the aquaculture segment of the state of $\mathrm{WB}, 68 \%$ of the farmers surveyed in 2006 had training in aquaculture and $15 \%$ had graduate degrees, while in the state of AP, the rates were $41 \%$ and $2.7 \%$, respectively. About $60 \%$ of the farmers in the state of AP learned disease management from the feed and drug sales personnel (Abraham et al., 2010).

A universal health care system is virtually nonexistent in India. Life expectancy has increased from 60 to 67 years between 1990 and 2011, and the infant mortality rate improved from $8.0 \%$ to $4.6 \%$. In comparison, China's numbers are 77 years and 1.6\%, respectively (Index Mundi, 2012). More than $75 \%$ of India's population has a per capita consumption below 2100 and 2400 calories/day in urban and rural areas, respectively (2400 and 2800 calories/day are optimal). Attention was not paid to the consumption of protein and micronutrients, which led to a vicious cycle of malnutrition, low productivity, low wages and malnutrition (Jha, Bhattacharyya, \& Gaiha, 2011). In the past, Channa (2010) urged for minimum-wage determination based on 2700 calories/day. Fish protein is considered as 'protein for the poor,' but only $28.2 \%$ of the rural and $20.9 \%$ of the urban households consumed fish in a seven day period in 2010. The total per capita fish consumption stands at $6.08 \mathrm{~kg} /$ year (NSS 66, 2012) and is forecasted to reach $15 \mathrm{~kg} /$ year by 2030 considering poor households to respond more positively to the higher income. As stated previously, the increasing trends of India's household disposable income and the total expenditure per household is anticipated to translate into more spending on fish because of its cheaper price than other meat products. This would therefore lead to higher demand for fish in the future as the elasticity of demand for fish products was determined as 1.66 (Jayasankar, Mishra, Sahu, Giri, \& Saha, 2011) which is comparatively higher than other meat products.

An organizational culture of a company is generally built on a firm's values and the country's culture in which it operates (Burman, 2010). Hofstede (2009) stated that "there is no special national culture for executives,... National cultures have centuries-old roots and their differences are unlikely to disappear" (Hofstede, 2009, p. 486). India being a multi-cultural and multi-plural society; cross-cultural literacy eases operational barriers for foreign executives interacting with Indian executives. The family is the most influential means of socialization, followed by caste, religion, and school. The collectivist mind-set, emotionality at work, and dependency proneness, all have links to family, which provides emotional security while the 'hierarchy orientation' originated from caste-based thinking. Depending on the place, time, and person or role, a typical Indian may choose to exhibit a fixed core-based behavior (values, beliefs and assumptions) or a flexible surface-part of the culture (style, fads, food, symbols, etc). Especially the surface-part was attributed to the variability in the behavior of the Indian management. A social institution called middle class is emerging in India which is stratified on the basis of occupation, education, and income levels, rather than traditional hierarchy. This class is still in the process of transformation and it could potentially bridge the cultural gap between an international firm and an Indian company. In summary, the acceptance of power inequality, low uncertainty avoidance, collectivism, and long-term orientation for the business results etc., paint the picture of the four major values in Indian organizational culture. Built on empirical results and the traditional view of the Indian culture, Arora (2005) prescribed a leadership style that combines authoritativeness, emotionality, empathy and result-orientation. He indicated that an Indian employee is flexible to work in all kinds of efficiency- and result-driven environments, if his/her 'cultural-needs' such as the desire of 'belonging to a big family' are fulfilled.

\subsection{Technological Landscape}

Technology is a vector to translate a concept into commercial value (Malhotra, 2011) and it is an essential tool for firms to compete in the globalized world (Schwab, 2011). English is one of the major languages in the world and it is estimated that nearly $20 \%$ of Indians are adept in this language giving India a competitive advantage over other countries in a knowledge-based economy (Datamonitor, 2011). To develop talent, 300 educational and research centers offer biotechnology degree programs (Chakraborty \& Agoramoorthy, 2010) and more than a dozen fisheries colleges offer courses in Fisheries Science and Aquaculture in each state (Ayyappan \& Gopalakrishnan, 2006). The College of Fisheries in Mangalore was the first to offer courses in aquatic medicine, 
pharmacology and toxicology which enables the graduates to prescribe therapeutics for the aquaculture industry (The Fish Site, 2012). The Finishing School Program for student training in the industry and the Biotechnology Associateships for training midcareer scientists (IBEF, 2011; Natesh \& Bhan, 2009) are other initiatives to develop skillful resources for the industry. Bagchi-Sen and Smith (2008) have concluded that the Welcome Trust Fellowship and the Ramalingaswami Re-entry Fellowship program have delivered their goals in reversing the brain-drain and fostering biotechnology companies.

Metcalfe defined a National Innovation System (NIS) as the framework of institutions and government policies that promote the innovation process by institutional collaboration (Bagchi-Sen \& Smith, 2008) and Raman (2010) described a technology management strategy for India as one that benefits the mass rather than a selected few. The Ministry of Science and Technology (MoST) is the apex body in India that develops the NIS for India under which the Indian Science and Technology Policy of 2003 (Fan, 2011) and the NBDS of 2008 were created to enhance institutional infrastructure and collaborations across sectors (Natesh \& Bhan, 2009). The Biotechnology Industry Partnership Program envisions forging PPP with allocation of INR 350 crore ( USD 79 million) during the $11^{\text {th }}$ five year plan (2007-2011). The benefits lie in the learning process for public and private sectors through partnerships (Mohan, 2011); this is especially true for public laboratories that are to earn at least $30-50 \%$ of their R\&D expenses either by retaining equity holdings in private enterprises or by out-licensing their technologies (Fan, 2011). To address the challenge of transferring and managing intellectual property (IP), the R\&D Bill of 2007 was introduced (Natesh \& Bhan, 2009). In the fishery sector, the National Mission for Protein Supplements, with an outlay of INR 100 crore ( USD 22.3 million) was initiated to enhance the fish productivity in 12 states (Raghu, 2011).

The institutional infrastructure is vital for the progress of research and innovation in any country and in this effort, the Department of Biotechnology (DBT) has set up 35 facilities, which include examples like microbial culture collections, cell lines, gene banks (IBEF, 2011), a bioinformatics network called BTISnet-BioGrid India (Natesh \& Bhan, 2009), etc. To maximize synergies, efficiency and to build successful enterprises, cluster development was undertaken with 26 operational biotech parks across India (IBEF, 2011) and 10 new biotech parks being built, of which the Marine Park in Karnataka is fishery specific (SiliconIndia News, 2011). In comparison, China has more than 153 bioindustry parks to date. Research and Development spending in India is encouraging. In the past, it spent $0.90 \%$ of its GDP on R\&D, while China invested $1.90 \%$ in 2010 . It has been postulated that a minimum of $2.0 \%$ of GDP spending is required to see significant progress in innovation (Mroczkowski, 2011). The MoST ramped up investments in India's R\&D by $173 \%$ from the last five year plan to INR 90000 crore ( USD 17.93 billion) in the $12^{\text {th }}$ five year plan (2012-2016), reaching the $2.0 \%$ mark (IBEF, 2012). Accordingly, in the 2012 Union Budget, the MoST has allocated INR 1485 crore ( USD 267 million) to the DBT which is an increase of about 10\% from 2011 (GOI-DBT-Budget-Notes, 2012). Comparatively, only a $3 \%$ increase was allocated to the entire Fisheries Program (GOI-DAHDF-Budget-Notes, 2012).

Biotechnology is increasingly employed in developing new breeds, feeds and improving fish health in India (Jayasankar et al., 2011). In parallel, culture technologies such as intensive and semi-intensive mono- or polyculture, modified-extensive and extensive farming, etc. (Abraham et al., 2010) are being developed for vertical expansion while technologies like remote sensing by satellite imaging and geographical information system are being employed to promote the current seven and 15 new species (Ayyappan \& Gopalakirshnan, 2008) into horizontal expansion. To tackle the diseases, experimental vaccines (Behera \& Swain, 2012; Khushiramani et al., 2012) and probiotics (Parthasarathy \& Ravi, 2011) are being evaluated.

One way of measuring innovation capacity is by determining the number of granted patents and peer-reviewed journal publications (Buchandiran, 2011). A comparison of patents in the US Patent Office in 2011 revealed that India and China received 1259 and 3786 granted patents, a 10 and 24 fold increase, respectively from 2000 (U.S. PTO, 2011). Similarly, between 2001 and 2011, the Science and Technology (S\&T) publication productivity showed that India ranked $11^{\text {th }}$ by volume (293 049 papers) while China and South Korea took the $2^{\text {nd }}$ (836 255) and $12^{\text {th }}(282328)$ places, respectively (Science Watch, 2011). The move of India from $12^{\text {th }}$ position in 2008 (Gupta \& Dhawan, 2008) to $11^{\text {th }}$ in 2011 indicates an improvement in publication output.

According to the 2011-2012 GCR, India ranked 93 out of 142 countries in technological readiness for its ability to improve the business efficiency and competitiveness by leveraging the Information and Communication Technologies. Improvements to business sophistication, entry barriers, environment for innovation, R\&D investment, and protection of the Intellectual Property Rights were noted as the key drivers for future success of India's innovation (Schwab, 2011). 


\subsection{The Legal Environment in India}

The legal system of an entry country protects an entrant to effectively manage the business with freedom to operate within the defined legal boundaries, to protect its intellectual property, and to recoup the costs incurred in R\&D. The legal framework in India is thorough and based on the English Common Law (Political Structure, 2011) with a three-tier judiciary system (the Supreme Court, 21 High Courts and Civil Courts). The Companies Act of 1956 and the Indian Contract Act of 1872 define business and corporate laws while the Foreign Trade Act, 1992 defines international trade laws. The value-added tax under which a foreign corporation pays $7.0 \%$ more than the domestic corporation was introduced in 2005. A domestic business is subject to a tax rate of $37.5 \%$ (Datamonitor, 2011). An additional (alternate) tax at $2.0 \%$ of the value of the gross assets is payable as per the Direct Tax Code (DTC). Corporate taxation is further reformed through DTC, which along with the Goods and Services Tax, if approved in the parliament may reduce the tax burden to $30.0 \%$ for new and existing businesses (PTI, 2012).

Table 1. Approval list from various government agencies to start a business in India (Ray, 2011)

Clearances / Approvals from Central Government

1. Obtaining Director Identification Number

2. Obtaining digital signature certificate

3. Reserving the company name with the Registrar of Companies

4. Presenting the company documents duly stamped by Superintendant of Stamps or the authorized bank along with the registration fee to the Registrar of Companies to get the Certificate of Incorporation

5. Obtaining a Permanent Account Number from National Securities Depository Services Limited or Unit Trust of India Investor Services Limited or their authorized agent

6. Obtaining a Tax Account Number for tax deduction at source from Income Tax Department

7. Obtaining environmental clearance under Environment Impact Assessment Notifications of 2006

8. Clearance for diversion of forest land

9. Clearance from Coastal Zone Regulation (CRZ) under CRZ Notification

10. Wildlife clearance under Wildlife ( Protection) Act, 1972

11. Stack height clearance under Aircraft Act, 1934

12. Clearances required from Ministry of Defense

13. Clearances under Electricity Act, 2003

14. Clearance to use groundwater in regions where water is in short supply

15. Security clearance

16. Obtaining importer-exporter code

Clearances / Approvals from State / Local Government

1. Approval of building plans by Municipal authorities and Factory Inspectorate

2. License from Chief Inspector of Factories under the Factories Act, 1948

3. Permission to use water and power

4. Consent to establish, operate, and grant of emission and discharge from Pollution Control Board

5. Registrations under labor laws such as Provident Fund and Employees State Insurance

6. Registration with value added tax and professional tax authorities

7. Registration under Shops and Establishment Act.

Regulatory reforms started in 1992 with the establishment of Securities and Exchange Board of India (SEBI) to regulate equity trading (Datamonitor, 2011). In 2000, a regulatory framework on corporate audits and governance for listed companies was formulated followed by the Competition Act of 2002 (GOI-Corp.Govern). The Industrial Disputes Act of 1947 governs retrenchment, closure, and layoffs, and a firm employing more than 100 people requires prior approval on business closure or downsizing (Ray, 2011). The government approvals required to set up a business in India are listed in Table-1.

India has amended its patent law since its introduction in 1995 and has developed a Patent Dispute Resolution System followed by granting patents since 2005 with a clause 3(d), according to which a product should have significant improvement in novelty from its previous version to qualify for an extension (Bhola, 2012). Compared to the US patent law, which often grants patents on trivial improvements to a product, India's patent law is considered more stringent (Shetty, 2012) and it takes about four years and costs USD 2000 to grant a patent in India (Bhola, 2012). 
Table 2. The regulatory path and timelines for registration of veterinary biologics in India

\begin{tabular}{|c|c|}
\hline \multicolumn{2}{|l|}{ Registration of Inactivated \& Killed Bacterial/Viral Vaccines in India } \\
\hline Procedure & $\begin{array}{l}\text { Other Agency Guidelines of } \\
\text { Importance }\end{array}$ \\
\hline $\begin{array}{l}\text { 1. A license to manufacture test batches of vaccines is required from FDA Bhawan, } \\
\text { New Delhi. (http://www.cdsco.nic.in/test_licences.htm) }\end{array}$ & \multirow{2}{*}{$\begin{array}{l}\text { 1. Aquatic Animal Health } \\
\text { Code. } 14^{\text {th }} \text { Ed, } 2011 \text {. World } \\
\text { Organization for Animal } \\
\text { Health. OIE. Paris. } \\
\text { http://www.oie.int/doc/ged/ } \\
\text { D10907.PDF }\end{array}$} \\
\hline $\begin{array}{l}\text { 2. A Release Certificate }(\mathrm{RC}) \text { will be issued by Biological Standardization, Indian } \\
\text { Veterinary Research Institute (IVRI) after samples from test batch meets } \\
\text { specifications (pre-clinical toxicity studies are not required for veterinary biologics). }\end{array}$ & \\
\hline $\begin{array}{l}\text { 3. No Objection Certificate (NOC) must be obtained from Drug Control General } \\
\text { (India) [DCG(I)], CDSCO, New Delhi before conducting clinical trial in required } \\
\text { species by enclosing RC from IVRI along with complete dossier. }\end{array}$ & \multirow{3}{*}{$\begin{array}{l}\text { 2. VICH guidelines for the } \\
\text { manufacture, testing, and } \\
\text { facility and equipment } \\
\text { validations may be found in: } \\
\text { http://www.vichsec.org/en/g } \\
\text { uidelines2.htm }\end{array}$} \\
\hline $\begin{array}{l}\text { 4. After six weeks post submission, the Licensee will be invited to DCG (I), New Delhi } \\
\text { for a technical presentation. }\end{array}$ & \\
\hline 5. Once clinical field trials in target species are complete, submission of Form- 44 for & \\
\hline $\begin{array}{l}\text { New Drug Approval is required with complete dossier with clinical trials reports. In } \\
\text { parallel, a license to manufacture commercial scale batches has to be obtained from } \\
\text { each of the following agencies: respective State Licensing Authority, Central } \\
\text { License Approving Authority, Concerned Zonal/Sub-zonal Offices of CDSCO. The } \\
\text { procedure is defined in the link: http://cdsco.nic.in/html/seravacci.html and the } \\
\text { cGMP guidelines and containment standards are provided in: } \\
\text { http://cdsco.nic.in/html/GMP/ScheduleM(GMP).pdf }\end{array}$ & \multirow[t]{3}{*}{$\begin{array}{l}\text { 3. USDA-APHIS Code of } \\
\text { Federal Regulations, Title 9, } \\
\text { animal vaccines and testing } \\
\text { requirements, may be found } \\
\text { at: } \\
\text { http://www.aphis.usda.gov/a } \\
\text { nimal_health/vet_biologics/ } \\
\text { vb_vs_memos.shtml }\end{array}$} \\
\hline 6. A second visit to DCG (I) may be required for the technical presentation. & \\
\hline $\begin{array}{l}\text { 7. After the review of the complete dossier, which may take anoth } \\
\text { will issue a Marketing Authorization. The licensing procedure } \\
\text { forms are presented in the web link: } \\
\text { http://cdsco.nic.in } / \mathrm{html} / \text { copy } \% 20 \mathrm{of} \% 201 . \% 20 \mathrm{~d} \& \text { cact121.pdf }\end{array}$ & \\
\hline \multicolumn{2}{|c|}{ Registration of r-DNA Vaccines and Vaccines derived from Live Modified Organisms (LMOs) in India } \\
\hline $\begin{array}{l}\text { 1. In addition to the requirements as stated above, additional approvals and NOC are } \\
\text { required from various review committees before submitting the dossier to DCG (I). } \\
\text { The guidelines and regulations for r-DNA products can be found in: } \\
\text { http://dbtindia.nic.in/guidelines_90.pdf }\end{array}$ & \multirow[t]{2}{*}{$\begin{array}{l}\text { 1. Some of the guidelines for } \\
\text { r-DNA and LMO vaccines } \\
\text { from international agencies } \\
\text { may be found in the web } \\
\text { links provided above. }\end{array}$} \\
\hline $\begin{array}{l}\text { 2.It may take between 6-18 months for the review and approval of r-DNA or LMO } \\
\text { vaccines in India (Sahoo \& Manchikanti, 2011) and the licensing procedure is } \\
\text { outlined in } \\
\text { http://dbtbiosafety.nic.in/steps/rpharma_tf_Mashelkar_Committee_Notification.p } \\
\text { Biosafety rules and roles and responsibilities of various committees can be found }\end{array}$ & \\
\hline
\end{tabular}

Commenting on the current biotechnology regulatory system in India, Dhawan (2010) pointed out that the responsibilities are spread across the Ministries of Agriculture, Environment and Forests, and Science \& Technology, while Scoones (2012) suggested adopting an established regulatory framework from elsewhere in the future. The Central Drugs Standard Control Organization (CDSCO) and the Genetic Engineering Approval Council (GEAC) are the apex bodies that regulate biological products in India. At the state level, 35 Food and Drug Administrators - one in each state - accredit manufacturing plants and conduct the quality audits (Kak, 2009). Sahoo and Manchikanti (2011) surveyed the Indian biotechnology industry and found that $89 \%$ of the firms followed the International Conference on Harmonization (ICH) guidelines to achieve quality standards in the absence of clear product specifications. Currently, a 'single window clearance system' and interaction with the regulatory reviewer(s) are not available as a result of which the registration process takes a minimum of two years to obtain a marketing authorization. Some critical steps involved in the registration and the respective forecasted timelines are presented in Table 2 (Personal Communication). 
Law enforcement in India is almost non-existent and the laws remain ineffective. It was estimated that over 31 million cases of law infringement were pending in 2010 in various courts with an estimated duration of around 320 years to clear the backlog (Datamonitor, 2011). The IPR activism is gaining momentum, but only in the national interest as illustrated by the issuance of the first 'compulsory license' on Bayer's patented cancer drug 'sorafenib- tosylate' to Natco Pharma Ltd on March 09, 2012. Critics argued that Bayer's high selling price was unaffordable for Indian patients, demonstrating the country's defensive stand on its generics industry (Shetty, 2012). Similarly, Novartis was stopped from 'evergreening' its Gleevec patent in 2009 on the basis of Clause 3(d). Due to the reasons of lack of proper resources, over 153 pre-granting oppositions and 29 patent litigation cases were pending in Indian courts by the end of 2009 and 2011 respectively (Bhola, 2012).

On the environmental front, Curmally (2002) pointed out the fragmented approach of the State Pollution Control Boards (SPCB) and the Central Pollution Control Board (CPCB) in implementing the environmental policies. In spite of many laws to control pollution, only two convictions occurred in the entire country up to 2007 (Chatterjee, 2009). To address this poor situation, India launched 'Green Courts' on October 19, 2010, the third country after Australia and New Zealand, to implement the 'Polluter Pays' policy and stepped up enforcement of the country's environmental laws. Under this policy, on May 26, 2011, the Haryana SPCB ordered the closure of 639 polluting companies identified in 2010 and also launched trials against 151 polluting units in the Special Environment Courts and made them install 9,239 units of pollution control devices (India-Pollution). Historically, such environmental laws were enforced on the owners of intensive prawn culture who destroyed the ecological systems by practicing intensive prawn aquaculture and were ordered to pay six years worth of wages as compensation to their affected workers (GOI-Supreme Court, 1996). The impact of these new governance processes may likely change the current poor rating of India's $125^{\text {th }}$ position among 132 countries in the 2012 Environmental Performance Index in the coming years (Emerson et al., 2012).

\section{Discussion}

Indian aquaculture is forecasted to deliver between 8-10 million tons of food fish by 2020. But without effective tools to counter and prevent diseases, vertical expansion is highly unlikely. The current practices of disease management through the use and abuse of antimicrobials (including antibiotics) and other drugs are not sustainable due to deleterious impacts on the environment and human health.

The political system in India is relatively stable, although the weakness of the coalition government and diverse political agendas of different states are impeding the creation of a business-friendly environment. Disparity in property rights may hinder a new entrant to choose the appropriate location for the business if building a new facility is a goal. Policy changes and implementation occur in India at a slower pace than elsewhere; hence a new entrant may need to be patient until the changes are realized. The governments' interest in a knowledge-based economy has further propelled the economic liberalization since 1991 for industries like biotechnology under which the fish vaccines sector falls. The Indian economy is gaining momentum in transitioning from factor-driven to an efficiency-driven economy like China and has established the institutional infrastructure equivalent to the innovation-driven economy in South Korea. The GDP growth rate is forecasted to reach $7.5 \%$ by 2013 up from $6.9 \%$ in 2012 . The role of the fisheries sector and its $5.93 \%$ contribution to India's agricultural GDP in 2005 was promising and as a result has attracted the attention of Indian politicians making a further strengthening of this business segment likely. Fiscal indicators such as the household savings rate, disposable incomes and the discretionary spending per household are increasing at a rapid rate. Such growth in fiscal parameters indicates improvements in spending capacity, which may translate into increased future consumption of fish, especially in the Indian poor households that respond more positively to a higher income. Additionally, the increasing trend of total per capita fish consumption to $15 \mathrm{~kg} / \mathrm{year}$ by 2030 means an increase in demand for fish products, which may translate into further attractiveness for aquaculture segment. The inflation rate is being controlled by tightening the monetary policy and is expected to be reduced to $4.0 \%$ by 2016. Therefore, borrowing costs are going to remain high in addition to transaction costs such as informal payments which are expected to be paid to the authorities and constitute some of the challenges to a new market entrant. The next steps for the government are to improve the governance indicators reported in the 2011-2012 GCR and to leverage the PPP to reap the benefits. Investments in the fisheries sector are also expected to improve the innovation in the sector and the Model Bill is anticipated to legislate the use of vaccines in place of chemotherapeutics for aquaculture sustainability which would be in favor of the new entrant. The technological landscape and IPR activism are improving which is key for a new entrant to develop novel products and protect its intellectual property.

To accelerate the establishment of a new vaccines business in India and to reach the market at the earliest point in time possible, an entry mode of choice could be a joint venture (JV). In this approach, the entrant could avoid 
the additional corporate taxes of up to $7.0 \%$ imposed on a wholly-owned foreign enterprise as per India's current taxation system. Since the partnering firm is assumed to have established infrastructure, distribution and marketing channels, as well as an established relationship with the regulators, the firm could realize the revenues in the earliest time possible, which in this case is expected to be within two years.

As per the competitor analysis, currently the Indian market does not have a direct competitor in the fish vaccines business sector and the likely competition will come from substitute (chemotherapeutics) manufacturers. Therefore, the new entrant may have the first mover advantage of securing a high market share in fish vaccines while also being able to set value-based but affordable prices for the vaccines, such that the initial entrant could impose entry barriers on potential future entrants. Improvements to India's regulatory system are vital as the regulations are not clearly defined for veterinary vaccines. Since most of the biotechnology firms dealing with human health products in India are using the ICH Technical Requirements for Registration of Pharmaceuticals for Human Use guidelines, a new entrant may follow the Technical Requirements for Registration of Veterinary Products (VICH) along with the Indian regulations and guidelines in order to comply with requirements for product approval.

Johnson and Tellis (2008) found that the drivers of success for a foreign entrant in India are a smaller firm size, less openness and less investment risk in an entry country, a mode of entry with greater control over business operations and a wholly-owned subsidiary. Although the authors' recommendations concur with only the first two drivers (smaller firm size, and less openness and less investment risk), the authors propose that the other two factors could be addressed in a JV mode, which is found to currently be the most popular mode of entry in India. The authors suggest that the entrant could gain substantial control over the partnership by first increasing the proportion of its equity in the JV; second, by delegating an expatriate leader who represents the entrant (if the entrant should be from outside India) thus gaining internal control by effectively managing the operations in India; and third, by in-licensing the patents and candidate technologies in the name of the entrant, rather than the Indian partner. According to the resource-based and the transaction-cost based theories, the higher the level of control, the higher the cost of operation (Johnson \& Tellis, 2008). Since the profit margins can be assumed to be greater than $40 \%$ in the vaccine business, these costs could be considered manageable. Other advantages of hiring an expatriate Indian is to bridge the cultural gap between India and a foreign investor group. The Indian market is considered less open by Western standard which favors the entrant, by creating a barrier for potential competition. To maximize the speed to market, an entrant could in-license the intellectual property or vaccine technology from national institutes in India and further continue its R\&D effort by partnering with the national fisheries institutes and leverages its human capital in developing products for the company. Two such examples of readily available technologies for in-licensing are the recombinant vaccines against Edwardsiella tarda (Behera \& Swain, 2012), and Aeromonas hydrophila (Maiti et al., 2012) to protect Carp from edwardsiellosis and dropsy diseases, respectively. This would mean that both the fisheries institute and the entrant would benefit from this partnership as the management of public research institutes are now mandated to generate income to cover their R\&D expenses through PPP or out-licensing technologies. By engaging in PPP, the entrant could leverage government funding thus expediting the future research program for fish vaccines. This strategy would mitigate the risk of investment for the entrant in building a R\&D facility and the risk of time lost in obtaining approvals from government agencies. In the JV mode, the partner in India is assumed to have the experience, networks and resources to allow the entrant to delegate the task of registering the new company to the Indian partner as it takes 23 approvals from various government agencies.

Direct advertisement is not an option in the biologics industry and since a network of fisheries institutes are well established in addition to veterinary institutes, it is vital that the JV partners direct efforts towards indirect marketing methods by disbursing the benefits of vaccines in these educational institutions, which may eventually pay off in the form of greater market adoption and sales for the firm.

\section{Conclusion}

In conclusion, the strategic macro-environmental factors in India indicate that setting up a fish vaccines business is feasible currently and the time for entry is favorable since there is no direct competition. However, some of the limitations that need careful attention include IPR, poor governance, the lack of a business-friendly environment, bureaucratic hurdles etc. In order for an entrant to move forward, following are some suggestions that the authors propose as topics for future research to complement the findings reported in this paper: (1) a primary market research to obtain data on the aquaculturists' needs and to develop an epidemiological (frequency and distribution of disease) map of the country; (2) a study to determine the market size and the attractiveness of fish vaccines; and (3) an evaluation of the competitive industry forces in the Indian aquaculture industry. 


\section{Acknowledgements}

The authors acknowledge and extend their gratitude to Dr. Pradip Kumar Das, Indian Immunologicals Limited, India, for sharing his insights on the regulatory paths and timelines for veterinary vaccines in India.

\section{References}

Aapo Länsiluoto, \& Tomas Eklund. (2008). On the suitability of the self-organizing map for analysis of the macro and firm level competitive environment: An empirical evaluation. Benchmarking: An International Journal, 15(4), 402-419.

Abraham, T. J., Sil, S. K., \& Vineetha, P. (2010). A comparative study of the aquaculture practices adopted by fish farmers in Andhra Pradesh and West Bengal. Indian Journal of Fisheries, 57(3), 41-48.

Aqua Overview. National aquaculture sector overview: India. Retrieved 05/05, 2012, from http://www.fao.org/fishery/countrysector/naso_india/en

Armstrong, G., \& Kotler, P. (2011). Marketing: An introduction. Boston.

Arora, D. (2005). Foreign multinationals in India: Adapting to India's work culture and management practices. Retrieved from http://people.f3.htw-berlin.de/Professoren/Arora/discussion_paper/Foreign_Multinationals_in_India-Dayan and_Arora.pdf

Ayyappan, S. (2006). Report of the working group on fisheries for the eleventh five year plan (2007-2012). Government of India. Retrieved from http://planningcommission.nic.in/aboutus/committee/wrkgrp11/wg11_rpfish.pdf

Ayyappan, S., \& Gopalakirshnan, A. (2008). Resilience in fisheries and sustainability of aquaculture. Paper presented at the $8^{\text {th }}$ Indian Fisheries Forum, Kolkata. 22-26 November 2008, 1-9. Retrieved from http://eprints.cmfri.org.in/8850/1/8th_Indian_Fisheries_Forum_Ayyappan.pdf

Ayyappan, S., \& Gopalakrishnan, A. (2006). Transgenics in fisheries: Perspectives, priorities and preparedness for India. Indian Journal of Fisheries, 53(2), 127-152.

Babatunde, B. O., \& Adebisi, A. O. (2012). Strategic environmental scanning and organization performance in a competitive business environment. Economic Insights - Trends \& Challenges, 64(1), 24-34.

Bagchi-Sen, S., \& Smith, H. L. (2008). Science, institutions, and markets: Developments in the Indian biotechnology sector. Regional Studies, 42(7), 961-975. http://dx.doi.org/10.1080/00343400701652800

Behera, T., \& Swain, P. (2012). Antigen adsorbed surface modified poly-caprolactone microspheres stimulates both adaptive and innate immune response in fish. Vaccine, 30, 5278-5284. http://dx.doi.org/10.1016/j.vaccine.2012.05.028

Bhan, M. K. (2006). Report of the working group for the eleventh five year plan (2007-2012). Department of Biotechnology, Government of India.

Bharathkumar, G., \& Abraham, T. J. (2011). Antibiotic susceptibility of gram-negative bacteria isolated from freshwater fish hatcheries of West Bengal, India. Indian Journal of Fisheries, 58(3), 135-138.

Bhola, R. (2012). Patent procurement and enforcement in India. Unpublished manuscript. Retrieved June 06, 2012, from http://www.bcic.org.in/recentevents/7Feb2012/MR._RAVI_BHOLA_PRESENTATION.pdf

BMIL. (2012). Chapter 4: Business environment. India Business Forecast Report, (3), 31-39.

Bourgeois III, L. J. (1985). Strategic goals, perceived uncertainty, and economic performance in volatile environments. Academy of Management Journal, 28(3), 548-573. http://dx.doi.org/10.2307/256113

Brugère, C., \& Ridler, N. (2004). Global aquaculture outlook in the next decades: An analysis of national aquaculture production forecasts to 2030. (No. Fisheries Circular No. 1001). Food and Agriculture Organization of the United Nations. Retrieved from http://www.fao.org/docrep/007/y5648e/y5648e00.HTM

Buchandiran, G. (2011). An exploratory study of Indian science and technology publication output. Library Philosophy and Practice, 1-9. Retrieved from http://unllib.unl.edu/LPP/buchandiran.pdf

Burman, R. (2010). Best practices for integrating talent across cultures \& geographies. Retrieved from http://www.worldatwork.org/waw/adimLink?id=36288

Chakraborty, C., \& Agoramoorthy, G. (2010). A special report on India's biotech scenario: Advancement in biopharmaceutical and health care sectors. Biotechnology Advances, 28(1), 1-6. 
Channa, S. M. (2010). What do people live on? Living wages in India. Anthropology of Work Review, 31(1), 15-29. http://dx.doi.org/10.1016/j.biotechadv.2009.10.007

Chatterjee, T. (2009). Reorienting environment policy in India towards a local area-based development and management paradigm. The Journal of Transdisciplinary Environmental Studies, 8(1), 1-16.

Chung-An, C. (2008). Linking the knowledge creation process to organizational theories: A macro view of organization-environment change. Journal of Organizational Change Management, 21(3), 259-279. http://dx.doi.org/10.1108/09534810810874778

Curmally, A. (2002). Environmental governance and regulation in India (India Infrastructure Report 2002). Retrieved from http://www.archidev.org/article.php3?id_article=597

Das, D., \& Gupta, R. A. (2007). A database on fish diseases, pathogens and related information. Journal of Interacademicia, 11(4), 528-532.

Datamonitor. (2011). Country analysis report: India. India Country Profile, 1-106.

Dhawan, V. (2010). Strengthening agricultural biotechnology regulation in India. TERI Policy Brief, Retrieved from http://www.teriin.org/policybrief/docs/TERI_PolicyBrief_Sept2010.pdf

Dipangka, S., \& Dibyendu, K. (2012). Immune responses and protection in Catla (Catla catla) vaccinated against epizootic ulcerative syndrome. Fish and Shellfish Immunology, 32, 353-359. http://dx.doi.org/10.1016/j.fsi.2011.11.030

Emerson, J. W., Hsu, A., Levy, M. A., de Sherbinin, A., Mara, V., Esty, D. C., \& Jaiteh, M. (2012). 2012 Environmental Performance Index and pilot trend Environmental Performance Index. New Haven: Yale Center for Environmental Law and Policy. Retrieved from http://epi.yale.edu/sites/default/files/downloads/2012-epi-full-report.pdf

Fan, P. (2011). Innovation capacity and economic development: China and India. Economic Change \& Restructuring, 44(1), 49-73. http://dx.doi.org/10.1007/s10644-010-9088-2

FAO. (2012). State of world aquaculture. Retrieved from http://www.fao.org/fishery/topic/13540/en

FAO. (2012). Aquaculture and inland fisheries. Retrieved from http://www.fao.org/fishery/topic/16021/en

FAO-Statistics. (2010). India-aquaculture country profile-statistics. Retrieved 05/05, 2012, from $\mathrm{http} / /$ www.fao.org/figis/servlet/SQServlet?ds=Aquaculture\&k1=COUNTRY\&k1v=1\&k1s=100\&outtype= html

Fifield, P., \& Gilligan, C. (1997). Strategic marketing management-planning and control, analysis and decision. Oxford: Butterworth-Heinemann.

Fombrun, C., \& Shanley, M. (1990). What's in a name? Reputation building and corporate strategy. Academy of Management Journal, 33(2), 233-258. http://dx.doi.org/10.2307/256324

French, P. (2011). Mothers of the nation. New Statesman, 140(5062), 24-27.

Gimeno, J., \& Woo, C. Y. (1996). Hypercompetition in a multimarket environment: The role of strategic similarity and multimarket contact in competitive de-escalation. Organization Science, 7(3), 322-341.

GOI-DAHDF-Budget-Notes. (2012). Demands for grants. Department of Animal Husbandry, Dairying and Fisheries. Budget Notes-2012-2013. Retrieved 06/15, 2012, from http://www.eximguru.com/content/Budget/Budget-2012-2013/Expnd/VOL2/sbe3.pdf

GOI-DBT-Budget-Notes. (2012). Demands for grants. Department of Biotechnology. Budget Notes-2012-2013. Retrieved 06/15, 2012, from http://www.eximguru.com/content/budget/budget-2012-2013/expnd/vol2/sbe87.pdf

GOI-MoF. (2011). Notification no. 21/2011-cus dated 1/3/2011. Retrieved from http://www.lawcrux.com/data5t/cu/cuncuv/71807.htm

GOI-Supreme Court. (1996). Indian prawn farming victory. Ecologist, 26(6), 4.

Goodnow, J. D., \& Hansz, J. E. (1972). Environmental determinants of overseas market entry strategies. Journal of International Business Studies, 3(1), 33-50.

Gupta, B. M., \& Dhawan, S. M. (2008). Status of India in science and technology as reflected in its publication output in Scopus international database, 1997-2007. (S\&T Output and Patents No. India, Science and Technology: 2008). Council of Scientific and Industrial Research. Retrieved from http://www.nistads.res.in/indiasnt2008/t5output/t5out1.htm 
Halim, U. (2010). Child labour in fishery and aquaculture: Need for a perspective. Paper presented at the Expert Consultation on Child Labour in Fisheries, April 14 to 16, 2010, 1-18. Retrieved from http://www.fao-ilo.org/fileadmin/user_upload/fao_ilo/pdf/WorkshopFisheries2010/WFPapers/UjjainiHalim WFFChildLabourFishery_Aquaculture.pdf

Hamel, G., \& Prahalad, C. K. (1994). Competing for the future. Boston, Massachusetts: Harvard Business School Press. Retrieved from

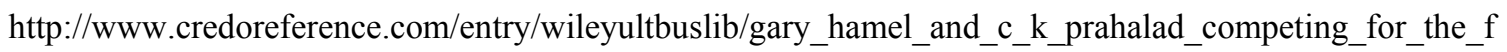
uture_1994

Harikrishnan, R., Balasundaram, C., \& Heo, M. S. (2012). Poly d, 1-lactide-co-glycolic acid (PLGA)-encapsulated vaccine on immune system in Epinephelus bruneus against Uronema marinum. Experimental Parasitology, 131(3), 325-332. http://dx.doi.org/10.1016/j.exppara.2012.04.017

Hill, C. W., \& Jones, G. R. (2006). Strategic management: An integrated approach $\left(7^{\text {th }}\right.$ ed.) Houghton Mifflin.

Hofstede, G. (2009). Business goals for a new world order: Beyond growth, greed and quarterly results. Asia Pacific Business Review, 15(4), 481-488. http://dx.doi.org/10.1080/13602380903102029

IBEF. (2011). Biotechnology. (Presentation). India: India Brand Equity Foundation. Retrieved from http://www.ibef.org/download/Biotechnology50112.pdf

IBEF. (2012). Science and Technology. Retrieved 10/06, 2012, from http://www.ibef.org/artdispview.aspx?in=65\&art_id=31243\&cat_id=126\&page $=2$

ICON Group. (2007). 2 macro-accessibility in India: 2.3 political risks. India Economic Studies, 20-21.

Index Mundi. (2012). Country facts 2012. Retrieved 06/15, 2012, from http://www.indexmundi.com/asia.html

Jayasankar, P., Mishra, B. K., Sahu, A. K., Giri, S. S., \& Saha, G. S. (2011). Vision-2030. India: CIFA, Ministry of Agriculture, GOI. Retrieved from http://www.cifa.in/admin/Files/Vision\%202030\%20Corrected.pdf

Jha, R., Bhattacharyya, S., \& Gaiha, R. (2011). Social safety nets and nutrient deprivation: An analysis of the NREG program and the public distribution system in India. Journal of Asian Economics, 22(2), 189-201.

Johnson, J., \& Tellis, G. J. (2008). Drivers of success for market entry into China and India. Journal of Marketing, 72(3), 1-13. http://dx.doi.org/10.1509/jmkg.72.3.1

Kak, A. (2009, June 30, 2009). Regulating biologics. Express Pharma. Retrieved from http://www.expresspharmaonline.com/20090630/expressbiotech02.shtml

Katiha, P. K., Jena, J. K., Pillai, N. G. K., Chakraborty, C., \& and Dey, M. M. (2005). Inland aquaculture in India: Past trend, present status and future prospects. Aquaculture Economics and Management, 9(1-2), 237-264. http://dx.doi.org/10.1080/13657300590961573

Keren, M. (2009). China and India-A note on the influence of hierarchy vs. polyarchy on economic growth. European Journal of Comparative Economics, 6(2), 325-346.

Khushiramani, R. M., Maiti, B., Malathi, S., Kallappa, S. G., Naviledasappa Akash, A., D., Karunasagar, I., \& Karunasagar, I. (2012). Recombinant Aeromonas hydrophila outer membrane protein 48 (Omp48) induces a protective immune response against Aeromonas hydrophila and Edwardsiella tarda. Research in Microbiology, 163(4), 286-291. http://dx.doi.org/10.1016/j.resmic.2012.03.001

Kumar, A. (2007). Indian biotech bazaar: A SWOT analysis. Biotechnology Journal, 2(5), 543-545. http://dx.doi.org/10.1002/biot.200700025

Kumar, A., Katiha, P. K., \& Joshi, P. K. (2003). A profile of people, technologies and policies in fisheries sector in India. Paper presented at the Proceedings Series 10. National Centre for Agricultural Economics and Policy Research, New Delhi, India. 1-171. Retrieved from http://www.ncap.res.in/upload_files/workshop/wspten.pdf

Kumar, B. G., \& Datta, K. K. (2008). Impact of science and technology on Indian fisheries sector. India, Science and Technology. http://dx.doi.org/10.2307/256862

Lumpkin, G. T., \& Dess, G. G. (1995). Simplicity as a strategy-making process: The effects of stage of organizational development and environment on performance. Academy of Management Journal, 38(5), 1386-1407.

Maiti, B., Shetty, M., Shekar, M., Karunasagar, I., \& Karunasagar, I. (2011). Recombinant outer membrane protein A (OmpA) of Edwardsiella tarda, a potential vaccine candidate for fish, Common Carp. 
Microbiological Research, 167, 1-7. http://dx.doi.org/10.1016/j.micres.2011.02.002

Maiti, B., Shetty, M., Shekar, M., Karunasagar, I., \& Karunasagar, I. (2012). Evaluation of two outer membrane proteins, Aha1 and OmpW of Aeromonas hydrophila as vaccine candidate for Common Carp. Veterinary Immunology and Immunopathology, 149(3-4), 298-301. http://dx.doi.org/10.1016/j.vetimm.2012.07.013

Malhotra, R. (2011). Science and technology on the eve of the $12^{\text {th }}$ plan. Current Science, 100(12), 1768-1774.

Mathew, J. C. (2008, Nov 17, 2008). Novartis to shift 100 jobs. Business Standard.

Miller, T., Holmes, K. R., \& Feulner, E. J. (2012). Highlights of the 2012 Index of Economic Freedom. The Heritage Foundation and The Wall Street Journal.

Mohan, S. R. (2011). Understanding interactions between research institutes and industry: Indian perspective. Journal of Technology Management for Growing Economies, 2(2), 113-138.

Mroczkowski, T. (2011). The new players in life sciences innovation: Best practices in $R \& D$ from around the world. The FT Press Operations Management.

Myint, S. (2011, May 16, 2011). India's vaccine manufacturing set to soar to $\$ 800 \mathrm{~m}$. India Post. Retrieved from $\mathrm{http} / /$ www.indiapost.com/indias-vaccine-manufacturing-set-to-soar-to-800m-prof-steven-myint/

Narasimhan, J. (2012). Medium- and long-term: Outlook. India Country Monitor, 26-28.

Natesh, S., \& Bhan, M. K. (2009). Biotechnology sector in India: Strengths, limitations, remedies and outlook. Current Science, 97(2), 157-169.

NSS 66. (2012). Household consumption of various goods and services in India, NSS-66 ${ }^{\text {th }}$ round, July 2009-June 2010. (No. 541). National Statistical Organization, GOI. Retrieved fromhttp://mospi.nic.in/mospi_new/upload/nss_report_541.pdf

Paroda, R. S., \& Praduman, K. (2000). Food production and demand in South Asia. Agricultural Economics Research Review, 13(1), 1-24.

Parthasarathy, R., \& Ravi, D. (2011). Probiotic bacteria as growth promoter and biocontrol agent against Aeromonas hydrophila in Catla catla (Hamilton, 1822). Indian Journal of Fisheries, 58(3), 87-93.

Pathak, S. C., Ghosh, S. K., \& Palanisamy, K. (Eds.). (2000). The use of chemicals in aquaculture in India. Aquaculture Department, Southeast Asian Fisheries Development Center.

Pereira, A. A. (2006). Biotechnology foreign direct investment in Singapore. Transnational Corporations, 15(2), 99-124. Retrieved from http://www.unctad.org/en/docs/iteiit20062a5_en.pdf

Political Structure. (2011). Political structure. Country Report. India, (11), 27-27.

Porter, M. E. (1986). Changing patterns of international competition. California Management Review, 28(2), 9-40. http://dx.doi.org/10.2307/41165182

Prime, P. B., Subrahmanyam, V., \& Lin, C. M. (2012). Competitiveness in India and China: The FDI puzzle. Asia Pacific Business Review, 18(3), 303-333. http://dx.doi.org/10.1080/13602381.2011.605673

PTI. (2012, Apr 12, 2012). GST rollout: SPV approved for IT support. The Times of India. Retrieved from http://timesofindia.indiatimes.com/tech/news/software-services/GST-rollout-SPV-approved-for-IT-support/ articleshow/12638627.cms

Raghu. (2011, August 6, 2011). Inland fisheries and aquaculture in India. Retrieved from http://appscmaterial.blogspot.ca/2011/08/inland-fisheries-and-aquaculture-in.html

Rajesh Kumar, S., Ishaq Ahmed, V. P., Parameswaran, V., Sudhakaran, R., Sarath Babu, V., \& Sahul Hameed, A. S. (2008). Potential use of chitosan nanoparticles for oral delivery of DNA vaccine in Asian Sea Bass (Lates calcarifer) to protect from Vibrio (Listonella) anguillarum. Fish \& Shellfish Immunology, 25(1-2), 47-56. http://dx.doi.org/10.1016/j.fsi.2007.12.004

Raman, N. (2010). Technology and entrepreneurship: How India can lead in creating a sustainable world future. Journal of Technology Management for Growing Economies, 1(2), 71-85.

Ray, G. (2011). Doing business in India: Opportunities and challenges. Journal of Marketing Development \& Competitiveness, 5(4), 77-95.

Sahoo, N., \& Manchikanti, P. (2011). Recombinant drug development, regulation, and commercialization: An $\begin{array}{llll}\text { Indian industry } & \text { perspective. }\end{array}$ http://dx.doi.org/10.2165/11584670-000000000-00000 
Schwab, K. (2011). The Global Competitiveness Report 2011-2012. World Economic Forum. Retrieved from $\mathrm{http} / / /$ www3.weforum.org/docs/WEF_GCR_Report_2011-12.pdf

Science Watch. (2011). Top 20 countries in all fields, 2001-2011. Retrieved 06/10, 2012, from $\mathrm{http}: / /$ sciencewatch.com/dr/cou/2011/11decALL/

Scoones, I. (2012). Getting hotter: Regulating biotechnology in India. The Crossing. (blog). Retrieved from $\mathrm{http}: / /$ stepscentre-thecrossing.blogspot.ca/2012/02/getting-hotter-regulating-biotechnology.html

Shetty, P. (2012, March 21, 2012). Novartis challenges India's patent law: Drug company up for rematch against clause prohibiting indefinite extension of patents. Nature News. Retrieved from $\mathrm{http}: / / \mathrm{www}$. nature.com/news/novartis-challenges-india-s-patent-law-1.10262

SiliconIndia News. (2011, May 05, 2011). By 2015 Indian biotech industry to reach $\$ 10$ billion. Retrieved from http://www.siliconindia.com/shownews/By_2015_Indian_Biotech_industry_to_reach_10_Billion-nid-8313 9-cid-3.html

Subasinghe, R. (2009). Disease control in aquaculture and the responsible use of veterinary drugs and vaccines: The issues, prospects and challenges. Options Méditerranéennes, (86), 5-11. Retrieved from http://ressources.ciheam.org/om/pdf/a86/00801057.pdf

Swain, P., Behera, T., Mohapatra, D., Nanda, P. K., Nayak, S. K., Meher, P. K., \& Das, B. K. (2010). Derivation of rough attenuated variants from smooth virulent Aeromonas hydrophila and their immunogenicity in fish. Vaccine, 28(29), 4626-4631. http://dx.doi.org/10.1016/j.vaccine.2010.04.078

The Economic Times. (2012, May 21, 2012). Unemployment on decline in urban, rural areas: Government. The Economic Times. Retrieved from http://articles.economictimes.indiatimes.com/2012-05-21/news/31800990_1_rural-areas-unemployment-rat e-urban-areas

The Economist. (2009, May 07, 2009). Economics focus: Opening the floodgates. The Economist. Retrieved from http://www.economist.com/node/13610915

The Fish Site. (2012, June 06, 2012). Fisheries course to include aquatic medicine. The Fish Site News Desk.

The World Bank. (2012). India economic update 2012. (No. 69403). The World Bank. Retrieved from http://www-wds.worldbank.org/external/default/WDSContentServer/WDSP/IB/2012/06/04/000386194_20 120604031449/Rendered/PDF/694030WP00PUBL0mic0Updata0March2012.pdf

Thukral, N., \& Dutta, R. (2012, Aug 2, 2012). India eyes rare feed grain imports after duty waiver. Reuters. Retrieved from http://in.reuters.com/article/2012/08/02/india-feed-imports-idINL4E8J21BF20120802

U.S. PTO. (2011). Patents by country, state and year-all patent types (Patent Technology Monitoring Team Report). USA: U.S. Patent and Trademark Office. Retrieved fromhttp://www.uspto.gov/web/offices/ac/ido/oeip/taf/cst_all.pdf

UN-HDI. (2011). Country profile: Human Development Indicators. Retrieved Aug 27, 2012, from http://hdrstats.undp.org/en/countries/profiles/IND.html

Walker, P. J., Lester, R. G., \& Bondad-Reantaso, M. G. (2005). Diseases in Asian aquaculture V-proceedings. Network of Aquaculture Centres in Asia-Pacific.

Weede, E. (2010). The rise of India: Overcoming caste society and permit-license-quota raj, implementing some economic freedom. Asian Journal of Political Science, 18(2), 129-153. http://dx.doi.org/10.1080/02185377.2010.492977

Wheelen, T. L., \& Hunger, J. D. (2002). Strategic management and business policy. Upper Saddle River, NJ. 